\title{
DEGRADATION OF IMMUNOGLOBULINS BY SECRETIONS OF HUMAN REPRODUCTIVE TRACTS
}

\author{
A. TJOKRONEGORO* AND S. SIRISINHA $\dagger$ \\ Department of Microbiology, Faculty of Science, \\ Mahidol University, Bangkok, Thailand
}

(Received 7th December 1973)

Although analysis of the humoral components of the external secretions has revealed the predominance of secretory immunoglobulin A (SIgA), trace amounts of serum-type IgA, IgG and IgM have also been detected (Tomasi, 1972). In the reproductive fluids, higher proportions of IgG have been observed (Acharya, Khambhla \& Goodman, 1968; Hulka \& Omran, 1969). The effectiveness of antibodies depends on whether or not they are stable in the environment in which they are to function. Seminal plasma is known to possess proteolytic activity, a condition that is generally unfavourable for the survival of ordinary proteins (Katsh, Aguirre \& Katsh, 1968; Suominen \& Niemi, 1970), and antibodies may not therefore be able to survive and function in these fluids. However, SIgA is known to be resistant to proteolysis (Cederblad, Johansson \& Rymo, 1966; Brown, Newcomb \& Ishizaka, 1970). The present study was designed to evaluate the structural stability of various classes of immunoglobulin (IgG, $\operatorname{IgA}, \mathrm{SIgA}$ and $\operatorname{IgM}$ ) in the secretions of male and female reproductive systems, and to follow changes in the biological activity of antibodies under the same experimental conditions

Semen samples were obtained from healthy adults by masturbation and were allowed to liquefy at room temperature for 15 to $30 \mathrm{~min}$. After centrifugation, the seminal plasma (SMP) was separated from the sediment and stored at $-20^{\circ} \mathrm{C}$. Cervical mucus was collected by aspiration from healthy adult women after insertion of a $15-\mathrm{cm}$ long blunt-tipped pipette directly into the external cervical os. The secretion was suspended in $2 \mathrm{ml}$ of $0.85 \% \mathrm{NaCl}$. The suspension was mixed thoroughly, centrifuged, and the supernatant cervical fluid $(\mathrm{CF})$ was removed and stored at $-70^{\circ} \mathrm{C}$. The SMPs used in this study were found to have moderate proteolytic activity, while pooled $\mathrm{CF}$ with a protein content of $185.0 \mathrm{mg} / 100 \mathrm{ml}$ had only weak activity (Charney \& Tomarelli, 1947).

The preparations of serum IgG, IgA and IgM and secretory IgA have been described (Sirisinha \& Charupatana, 1970; Tomasi, Tan, Solomon \& Prendergast, 1965). Purified Igs were trace-labelled with ${ }^{125} \mathrm{I}$ by the chloramine-T method (McConahey \& Dixon, 1966) and the labelled protein was separated

* Present address: Department of Biology, Faculty of Medicine, University of Indonesia, Jakarta, Indonesia.

$\dagger$ Reprint requests to Dr S. Sirisinha. 
from free iodine by gel-filtration. The preparation of monospecific rabbit antisera to purified Igs has been reported (Sirisinha \& Charupatana, 1970).

The titres of anti-A and anti-B isoagglutinins in the serum and SMP samples were measured by a microtitration technique (Sever, 1962). Antitoxic activity to tetanus toxin was determined by the in-vivo neutralization test (Sirisinha \& Charupatana, 1970). Immunodiffusion, immunoelectrophoresis, radial immunodiffusion and gel-filtration techniques were performed as described (Williams \& Chase, 1971).

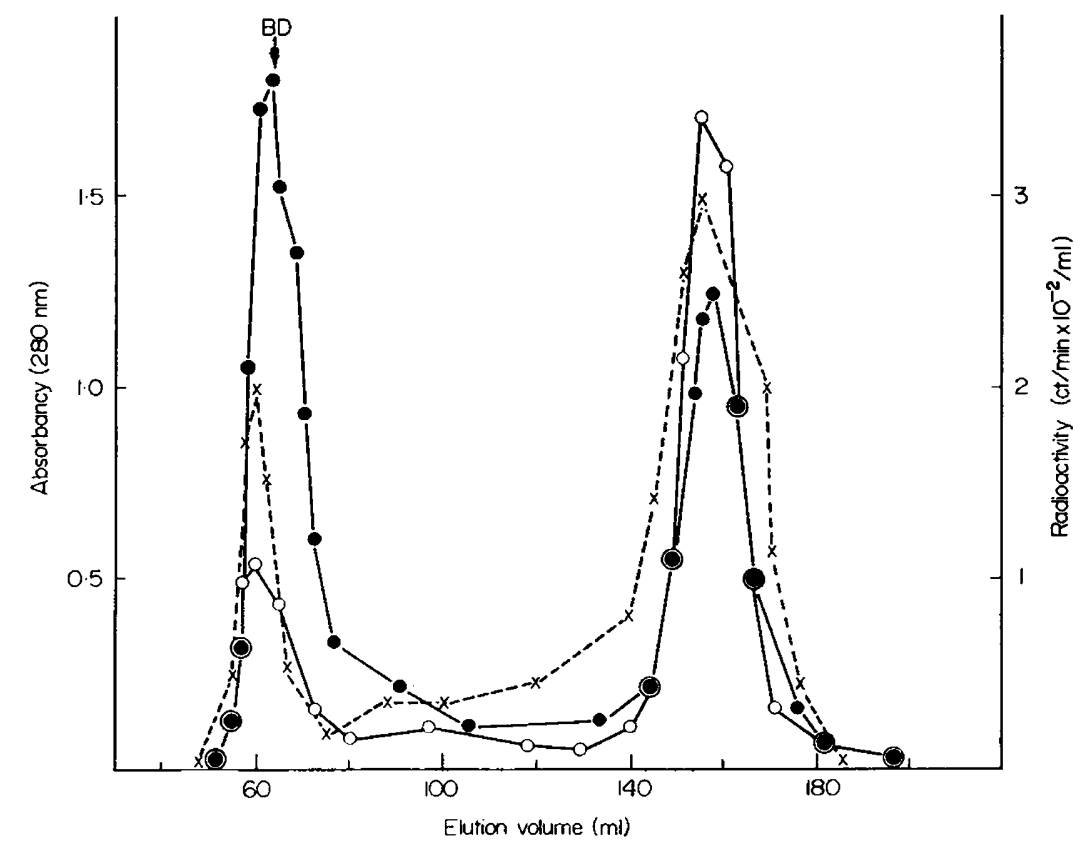

TexT-FIG. 1. The elution patterns of radioactive material from Sephadex G-150 column $(1.5 \times 90 \mathrm{~cm})$ following the application of unincubated $(\bullet)$ and incubated $(0)\left(37^{\circ} \mathrm{C}\right.$, $48 \mathrm{hr}$ ) ${ }^{125}$ I-IgA-human SMP mixture. The elution pattern of immunoglobulin used as starting material was heterogeneous. The elution pattern of a $280-\mathrm{nm}$ absorbing material from the same column is shown $(x)$. BD represents the elution position of blue dextran.

The effect of male and female reproductive fluids on the stability of Igs was investigated by analysing the immunochemical and physicochemical properties of purified Igs (IgG, IgA, SIgA and IgM) after being incubated with SMP or $\mathrm{CF}$. The functional integrity of antibodies treated under the same experimental condition was analysed by observing changes in the titres of antibody activities following incubation. In a typical experiment, Igs were mixed and incubated with fresh pooled SMP at $37^{\circ} \mathrm{C}$ and $4^{\circ} \mathrm{C}$ in the presence of $0.0001 \%$ merthiolate. For controls, the same Ig preparations were incubated with $0.85 \% \mathrm{NaCl}$ at $37^{\circ} \mathrm{C}$. At $6,12,24$ and $48 \mathrm{hr}$, small volumes of the mixtures were examined by immunodiffusion, immunoelectrophoresis and radial immunodiffusion. None of the four Ig preparations showed any detectable change when analysed by the first two methods. Some changes in the physicochemical structure of serum- 
type $\operatorname{IgA}$ and $\operatorname{IgM}$, but not IgG or SIgA, were observed when the incubated Ig-SMP mixtures were analysed by radial immunodiffusion.

To define further the changes that took place during incubation, the following experiments were conducted. Radioactive ${ }^{125} \mathrm{I}$-labelled Ig preparations were incubated with SMP or CF at $37^{\circ} \mathrm{C}$ for $48 \mathrm{hr}$. At the end of the incubation period, the samples were chromatographed on a Sephadex G-150 column and the distributions of radioactive material before and after incubation were compared. Products of each set of incubation conditions, i.e. Ig alone, SMP alone and Ig-SMP mixtures before and after incubation, were analysed on the same column. The elution patterns of all unincubated Ig-SMP mixtures were similar to those of the corresponding Igs used as starting materials.

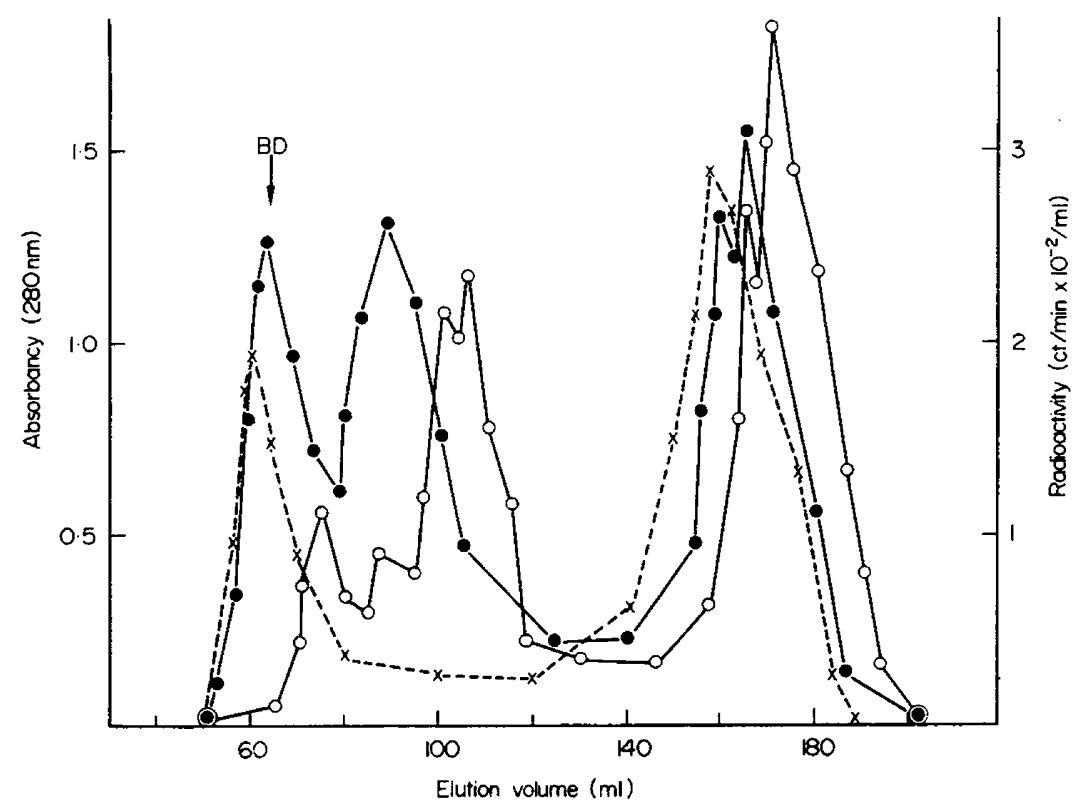

TEXT-FIG. 2. The elution patterns of radioactive material from Sephadex G-150 column $(1.5 \times 90 \mathrm{~cm})$ following the application of unincubated $(\bullet)$ and incubated $(0)\left(37^{\circ} \mathrm{C}\right.$, $48 \mathrm{hr}$ ) ${ }^{125}$ I-IgM-human SMP mixtures. For other details, see text and legend to Text-fig.1.

The elution patterns of radioactive IgG before and after incubation with SMP were similar and were therefore indistinguishable from that of the ${ }^{125} \mathrm{I}$ IgG alone. Similar results were obtained when SIgA was used in the experiment, but the elution pattern of the serum-type IgA incubated with SMP was slightly different from that of the unincubated IgA-SMP mixture (Text-fig. 1), as well as from the purified IgA preparation alone. After incubation, the radioactive peak eluted in the excluded volume accounted for $22 \%$ of the total activity compared to $44 \%$ in the unincubated mixture, while that of the second peak increased from $39 \%$ to $68 \%$. The elution pattern of IgM incubated with SMP was strikingly different from that of the unincubated mixture (Text-fig. 2). After incubation, the first peak largely disappeared and the radioactive counts fell from 25 to $7 \%$. A new small intermediate peak, eluted at the 76-ml 
position, appeared after incubation. The second radioactive peak of the incubated mixture eluted from the column after that of the unincubated mixture (at $107 \mathrm{ml}$ versus $89 \mathrm{ml}$ ). In addition, a total radioactive count in the third peak of the incubated mixture also increased from $40 \%$ to $56 \%$. These findings are consistent with the immunochemical observations discussed earlier and suggested that there was some degradation of IgM, and possibly of serum-type IgA, after prolonged incubation with SMP. No detectable change was observed when the Ig preparations were incubated with $\mathrm{CF}$.

The functional integrity of antibodies in SMP was examined by observing changes in their titres following incubation of SMP at $37^{\circ} \mathrm{C}$. The results indicate that the titres of isoagglutinins in the SMP from two donors of blood group $\mathrm{O}$ were almost totally destroyed following incubation at $37^{\circ} \mathrm{C}$ for $48 \mathrm{hr}$, i.e. the titre fell from $1: 8$ to less than $1: 2$. The isoagglutinin activities in these fluids were probably associated with an IgM class of antibody because they were susceptible to the reduction procedure commonly used to distinguish IgM from IgG in the serum (Ishizaka, 1970). By contrast, the antitoxic activity of two SMP samples from individuals hyperimmunized with tetanus toxoid, found to be associated with IgG-class antibody, was not affected under the same experimental conditions.

These results showed that SIgA and IgG were immunologically and functionally stable in the presence of SMP and CF. The finding that SIgA was not degraded following prolonged incubation with SMP was consistent with previous observations by other investigators (Cederblad et al., 1966; Brown et $a l ., 1970$ ) that SIgA is resistant to proteolysis. The resistance of IgG to proteolysis and the failure of prolonged incubation to alter the antibody activity of the IgG class are of particular interest because this class of Ig predominates in the secretions of the human reproductive tract (Acharya et al., 1968; Hulka \& Omran, 1969). The observations that IgM was degraded into smaller fragments following incubation were consistent with finding of Acharya et al. (1968) who reported that monospecific anti-IgM occasionally gave a second band of precipitation in the $\alpha$-globulin region when SMP was analysed by immunoelectrophoresis.

The stability of certain classes of immunoglobulin in SMP and CF suggest that some types of antibody can function in these environments and is of importance in connection with the functional rôle of the immune system in the reproductive tract, either in regulating fertility or as a defence against infections occurring at these sites. The appearance of $\operatorname{IgG}$ antibody in SMP following parenteral immunization and its stability in this fluid suggest the feasibility of the future development of suitable vaccines to regulate fertility as well as to protect against local infections.

These studies were submitted by one of us (A.T.) to the Faculty of Graduate Studies, Mahidol University, in partial fulfilment of the requirements for the degree of Doctor of Philosophy.

The work was supported by research grants from the Rockefeller Foundation and by the National Research Council of Thailand. The authors are grateful to the kind cooperation and suggestions of Dr Vitoon Osathanondh, Department 
of Obstetrics and Gynaecology, Faculty of Medicine, Ramathibodi Hospital, and to Dr Pornchai Matangkasombut for suggestions and criticisms.

\section{REFERENCES}

ACHARYA, U. S. V., Khambhla, A. \& Goodman, A. (1968) Immunoglobulins in human seminal plasma. Indian 7. Biochem. 5, 43.

Brown, R. W., Newcomb, R. W. \& Ishizaka, K. (1970) Proteolytic degradation of exocrine and serum immunoglobulins. $\mathcal{F}$. clin. Invest. 49, 1374.

Cederblad, G., Johansson, B. G. \& Rymo L. (1966) Reduction and proteolytic degradation of immunoglobulin A from human colostrum. Acta chem. scand. 20, 2349.

Charney, J. \& Tomarelli, R. M. (1947) Colorimetric method for the determination of the proteolytic activity of duodenal juice. F. biol. Chem. 171, 501 .

Hulka, J. F. \& OMran, K. F. (1969) The uterine cervix as a potential local antibody secretor. Am. 7 . Obstet. Gynec. 104, 440.

IshizAKA, K. (1970) Structure and function of immunoglobulins. In Biology of the Immune Response, p. 35. Eds. P. Abramoff and N. F. La Via. McGraw-Hill, New York.

Katsh, S., Aguirre, A. \& Katsh, G. F. (1968) Inactivation of sperm antigens by sera and tissues of the female reproductive tract. Fert. Steril. 18, 740.

McConahey, P. J. \& Dixon, F. J. (1966) A method of trace iodination of proteins for immunologic studies. Int. Archs Allergy appl. Immun. 29, 185.

SEVER, J. L. (1962) Application of a microtechnique to viral serological investigations. F. Immunol. 88, 320 .

Sirisinha, S. \& Charupatana, C. (1970) Antibody responses in serum, secretions, and urine of man after parenteral administration of vaccines. Infect. E Immunity, 2, 29.

Suominen, J. \& Niemi, M. (1970) Proteolytic enzymes in human seminal fluid. Scand. 7. clin. Lab. Invest., Suppl. 113, 52.

Tomasi, T. B., JR (1972) Secretory immunoglobulins. New Engl. 7. Med. 287, 500.

Tomasi, T. B., Jr, Tan, E. M., Solomon, A. \& Prendergast, R. A. (1965) Characteristics of an immune system common to certain external secretions. F. exp. Med. 121, 101.

Wicliams, C. A. \& Chase, M. W. (1971) Methods in Immunology and Immunochemistry, Vol. III. Academic Press, New York. 